\title{
Metals in Some Ready-to-Eat Foods on Some Highways of Lagos and Ota South-West Nigeria
}

\author{
Olumayowa Joshua Onipede ${ }^{*}$ and Nabiel Tolulope Rahman
}

Department of Chemical and Food Sciences, Bells University of Technology, Ota, Ogun State, Nigeria

"Corresponding author: Olumayowa Joshua Onipede, Department of Chemical and Food Sciences, Bells University of Technology, Ota, Ogun State, Nigeria, Tel: 09051675029; E-mail: mayowaonipede@yahoo.com

Received date: December 26, 2017; Accepted date: December 29, 2017; Published date: December 29, 2017

Copyright: ( $) 2017$ Onipede OJ, et al. This is an open-access article distributed under the terms of the Creative Commons Attribution License, which permits unrestricted use, distribution, and reproduction in any medium, provided the original author and source are credited.

\begin{abstract}
This research determined the concentration of Lead $(\mathrm{Pb})$ and Cadmium $(\mathrm{Cd})$ in roasted corn (Zea mays), roasted plantain (Musa paradisiaca) and barbecue from roadside close to industrial and automobile emission in some selected parts of Lagos and Ota, South-West Nigeria. They were analysed after digestion by Atomic Absorption Spectrophotometry (AAS). Lead had the highest concentration in all the food type analyzed and was higher than FAO permissible limit $(0.3 \mathrm{mg} / \mathrm{kg})$ in about $92 \%$ of the samples analyzed. It was also found to be higher in the samples from Lagos than those from Ota. While Cadmium had relatively lower concentration compared with Lead in all the food samples but about $25 \%$ of the samples analyzed had higher concentration than the FAO permissible limit $(0.5 \mathrm{mg} / \mathrm{kg})$. The results showed that the order of the concentration of Lead in the food samples was corn>barbecue>plantain, while the order of the Cadmium concentration in the food samples was in the order corn>plantain>barbecue. Continual consumption of roasted corn, roasted plantain and barbecue close to highway and industrial emission may therefore constitute a source of exposure to these heavy metals.
\end{abstract}

Keywords: Lead; Cadmium; Roasted food; Industrial emission; Automobile emission

\section{Introduction}

Heavy metals in food is generally through industry and vehicular emission; vehicular emission usually settle down on the roadside environment and could transverse up to $100-200 \mathrm{~m}$ from roadside and the vast majority deposited within $20 \mathrm{~m}$ of the roadside. These particulate deposits include metals like $\mathrm{As}, \mathrm{Cd}, \mathrm{Cr}, \mathrm{Hg}, \mathrm{Mn}, \mathrm{Ni}, \mathrm{Pb}, \mathrm{Se}$, and $\mathrm{Zn}$. These metals accumulate in the urban environment and their effect on roadside soil and potential effect tend to persist for a long time, they are from fuel, engine oil , tyre wear, brake wear and exhaust catalyst which makes the environment around roadside prone to metal pollution $[1,2]$. Studies which have reported high traffic pollution to be associated with asthma, high blood pressure, lung cancer, diabetes, Alzheimer's disease, dementia and even premature death [3].

Metals in the environment are important because of their accumulative and toxic nature [4]. They could also be a good indicator of environmental pollution [5]. The major source of exposure of humans to heavy metals is through food ingestion [6]. Heavy metal composition of food is of interest because of their toxic or even essential nature [7]. Consumption of food contaminated with heavy metals may deplete some essential nutrients in the body leading to reduction in immunological defence, intrauterine growth retardation, impaired psycho-social behaviour, disabilities related to malnutrition and increased prevalence of upper intestinal cancer [8].

Studies have shown that Lead has been implicated in health challenges such as fatigue, irritability, myalgia, coma, kidney, liver and brain damage seizures, encephalopathy, nervous system dysfunction and development of cancer while Cadmium is known to have caused the Itai-Itai disease in Japan as well as bone disease, anosmia, yellow discolouration of teeth and loss of olfaction abilities [9].
Regular absorption of small amount of heavy metal such as Lead has been reported as causing such effects in children as retardation of mental development, deficiency in concentration, adverse effect on kidney function, blood chemistry and cardiovascular system as well as hearing degradation, while high exposure could result in death [10-13]. Although it was said that in animal generally metabolic effect and Cadmium sensitivity could vary depending on the source of uptake diet or water borne exposure, effect on metal binding protein and Cadmium distribution within the body tissues [14]. However in human unborn baby, Lead and Cadmium have been linked to hormonal changes, impaired placental development, congenial malfunction, foetal growth restriction and spontaneous abortion [15]. Studies have shown that the effect may not be apparent not even until thirty years $[16,17]$.

Research on trace metals have focused on canned foods, agricultural products from polluted soil and application of manure in agriculture as a veritable source of metal pollution in the soil [18-21]. Emission from industries and automobile may increase considerably metal contaminant in soil and water [22] and hence lead to increase in heavy metal contribution to food $[23,24]$. However, little attention is paid to foods on industrial emission and high traffic routes, which gives sporadic contamination of pollutant through dry or wet atmospheric deposition and precipitation.

Pollutant emission in urban environment can travel far in the atmosphere because of temperature inversion [25]. High concentration of Lead, Chromium, Cadmium, Mercury and Arsenic are linked to airborne transport of pollutant from industrial, highway road and urbanization [23-26]. Automobiles emit several hundred of different compounds [27] hence the vehicular contribution to atmospheric pollutant of an environment cannot be underestimated as they contribute significantly to the level of trace metals in the environment. Vehicular contribution may be as a result of dust and exhaust obtained from burning of fossil fuel [16-28]. 
Research have established a positive correlation between heavy metal concentration and vehicular movement and that $\mathrm{Cu}, \mathrm{Pb}, \mathrm{Zn}, \mathrm{Ni}$ and $\mathrm{Cd}$ in urban areas are due to particulate deposition from vehicles on the highway [29]. Hence the effect of automobile contribution to the atmospheric pollution cannot be overemphasized, but there seems to be paucity of literature on the contribution of automobile and industrial emission to heavy metals in the atmosphere and subsequent deposition on road side roasted foods. The area is mainly industrial and residential with no space for cultivation, hence this work examine the direct deposition on the food. Corn is eaten by people of all ages in many African countries in many traditional forms, meat in form of barbecue is eaten by all classes of people, while plantain is a major food eaten all over the world a ter rice, corn and milk [30,31].

Cadmium and Lead are environmental pollutant toxic to humans and animals they are non-biodegradable and thus accumulate in the environment, thus this research examines the concentration of Lead and Cadmium in ready-to-eat roasted corn (Zea mays), roasted plantain (Musa paradisiaca) and barbecue on high traffic routes which may be close to industrial emissions in some parts of Lagos and Ota environment, South-West Nigeria, with the view of monitoring the highway and industrial contribution to these ready-to-eat roasted foods which may represent the exposure of the busy population who consume such foods.

\section{Materials and Methods}

\section{Sampling}

Plantain, roasted corn and barbecue samples were bought randomly at Tollgate (SP1), Agege (SP2) in Lagos and Joju (SP3), Oju ore (SP4) in Ota, Ogun state, South-West Nigeria. The control were bought at $5 \mathrm{~km}$ away from the Agege sample site, which was quite far away from high traffic routes and industrial particulate emission unlike the sample. They were wrapped in paper and kept in polythene bag and transported to the laboratory, and were stored in the freezer until the time of analysis.

\section{Digestion}

Roasted corn samples and controls were pounded in already washed and dried agate mortar and pestle after which were reduced to laboratory size samples of the bulk. Each of the samples was digested by method which involves digesting about $0.5 \mathrm{~g}$ of the representative sample in $6 \mathrm{ml}$ of $2 \mathrm{M}$, Nitric, Sulphuric and Perchloric acids mixed in the ratio 2:10:1 [32]. The digestion was done in $25 \mathrm{ml}$ screw cap centrifuge tube placed in boiling water bath until a clear solution was obtained. The same procedure for roasted was followed for roasted plantain samples and control samples. But each of the barbecue samples and control samples was pounded in already washed and dried agate mortar and pestle and reduced to get laboratory size sample, and was digested by taking about $0.5 \mathrm{~g}$ of the representative sample in $6 \mathrm{ml}$ of $5 \mathrm{M}$ Nitric acid. The digestion was done in $25 \mathrm{ml}$ screw cap centrifuge tube placed in boiling bath until a clear solution was obtained. Each of the digested samples and control samples was allowed to cool and was filtered through the filter paper and made up to $100 \mathrm{ml}$ mark with deionized water.

\section{Analysis}

The analysis was done by the thermo scientific series atomic absorption spectrometer serial no. GE 712354 v1.27 at $283.3 \mathrm{~nm}$ and
$228.8 \mathrm{~nm}$ for Lead and Cadmium respectively, and calibration curve of the standard concentration of Lead and Cadmium was obtained. Each of the concentration was extrapolated from the calibration curve. All the reagents used were analytical grade reagents and the water used in dilution was deionized water.

\section{Results and Discussion}

Cadmium concentration in roasted plantain (Musa paradisiaca) was in the range ND-0.57 $\pm 0.02 \mathrm{mg} / \mathrm{kg}$ (Table 1). This is higher than the concentration observed by Franca $(0.2 \mathrm{mg} / \mathrm{kg}$ ) (Figure 1$)$. In some cultivated lettuce exposed to heavy metals high traffic area of Pernambuco, Brazil [29]. This may bring credence to the fact that vehicular and industrial emission may be a veritable source of exposure heavy metals in food. Cadmium concentration in roasted plantain (Musa paradisiaca) was the second highest concentration after roasted corn. SP1 Tollgate analyzed was below the detection limit of Cadmium which represents $25 \%$ of the samples, this may be due to the fact that Tollgate had less influence from industries, but vehicular contribution seems to be the only source of pollution. However it was found that Cadmium concentration was higher at SP2 and SP4, Agege and Oju-ore respectively compared to SP1 and SP3, Tollgate and Joju respectively. This may be expected as Agege and Oju-ore have high vehicular movement as well as industrial emissions. Point variation of the Cadmium in the samples analyzed could be pointers to the impact of industrial and vehicular emission as genuine sources of exposure to heavy metals in roadside foods. Cadmium concentration in $75 \%$ of the samples analysed had lower concentration than the FAO recommended limit of $0.5 \mathrm{ppm}$ in food and additives [33].

\begin{tabular}{|l|l|l|}
\hline Sample sites & Cd $(\mathbf{m g} / \mathbf{k g})$ & $\mathbf{P b}(\mathbf{m g} / \mathbf{k g})$ \\
\hline SP1 & ND & $2.55 \pm 0.1$ \\
\hline SP2 & $0.47 \pm 0.02$ & $1.92 \pm 0.1$ \\
\hline SP3 & $0.46 \pm 0.02$ & ND \\
\hline SP4 & $0.57 \pm 0.02$ & $2.25 \pm 0.1$ \\
\hline Control & ND & $1.00 \pm 0.25$ \\
\hline SP=Sample Point ND=Not Detected & & \\
\hline
\end{tabular}

Table 1: Showing concentration of metals in roasted plantain (Musa paradisiaca) samples.

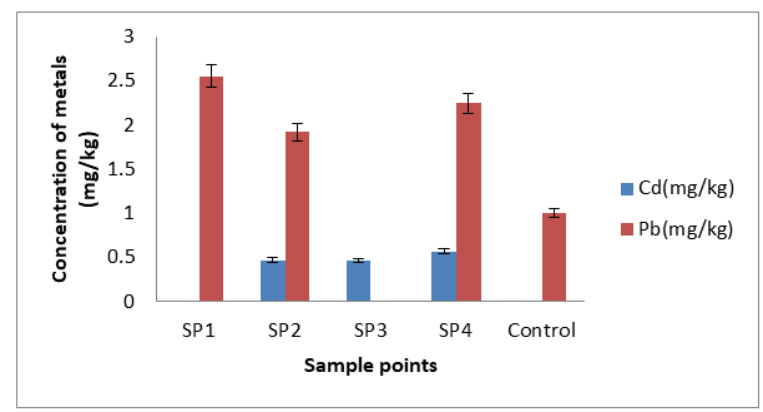

Figure 1: Showing chart of concentration of metals in roasted plantains (Musa paradisiaca). 
Lead concentration in roasted plantain (Musa paradisiaca) was in the range ND-2.55 $\pm 0.1 \mathrm{mg} / \mathrm{kg}$ (Figure 1). This is higher than that observed by Amos-Tautua in roasted plantain (Musa paradisiaca) which was $0.0048 \mathrm{ppm}$ on the average [34]. Generally Lead in roasted plantain was the least in concentration compared to what was obtained from roasted corn and barbecue. Samples from SP3, Joju analysed had concentration below the detection limit of Lead this sample point represents $25 \%$ of the samples. The trend of Lead concentration in roasted plantain (Musa paradisiaca) was however different from that obtained in Cadmium as Lead concentration was found to be higher at SP1 and SP4, Tollgate and Oju-ore respectively than those obtained from SP2 and SP3, Agege and Joju respectively. Tollgate and Oju-ore have high traffic, but industrial emission seems to contribute to the value obtained at Oju-ore. Lead concentrations were higher in $75 \%$ of all the samples than the FAO/WHO recommended limit of $0.3 \mathrm{ppm}$ in foods [33], but were lower than the limit in $25 \%$ of the samples analysed. Lead concentration in the control roasted plantains (Musa paradisiaca) which were far away from vehicular and industrial emission had lower concentration than in most samples but was still higher than the FAO/WHO recommended limit in foods. This could be as a result of other extraneous sources of metal contamination in foods which may include agricultural contribution from fertilizers and pesticides in the process of cultivation of the foods [29].

Cadmium concentration in barbecue samples was in the range ND- $0.23 \pm 0.01 \mathrm{mg} / \mathrm{kg}$ (Table 2). This is slightly less than that observed by Cai [22] in animals bred in unpolluted area of china, which was 2.15 ppm (Figure 2). SP1, Tollgate samples analyzed was below the detection limit of Cadmium which represents $25 \%$ of the samples. Cadmium in barbecue had the lowest concentration of Cadmium as compared to that obtained in roasted plantain and roasted corn. SP2 and SP3, Agege and Joju respectively seems to have higher concentration of Cadmium compared with that obtained from SP1 and SP4, Tollgate and Oju-ore respectively. This may be expected as Agege and Joju seems to have industrial contribution in addition to the vehicular contribution thereby, causing more particulate deposition as a result of both industrial and vehicular emission. The concentration of Cadmium in the control samples were lower than most of the samples analyzed in this study. But in general Cadmium in all the samples of barbecue were below the $\mathrm{FAO} / \mathrm{WHO}$ recommended limit of Cadmium in foods.

\begin{tabular}{|l|l|l|}
\hline Sample sites & $\mathrm{Cd}(\mathbf{m g} / \mathbf{k g})$ & $\mathrm{Pb}(\mathbf{m g} / \mathbf{k g})$ \\
\hline SP1 & ND & $9.01 \pm 0.45$ \\
\hline SP2 & $0.14 \pm 0.01$ & $7.62 \pm 0.30$ \\
\hline SP3 & $0.23 \pm 0.01$ & $3.30 \pm 0.17$ \\
\hline SP4 & $0.12 \pm 0.01$ & $5.28 \pm 0.30$ \\
\hline Control & ND & $1.05 \pm 0.04$ \\
\hline SP=Sample Point ND=Not Detected & & \\
\hline
\end{tabular}

Table 2: Showing concentration of metals in barbecue.

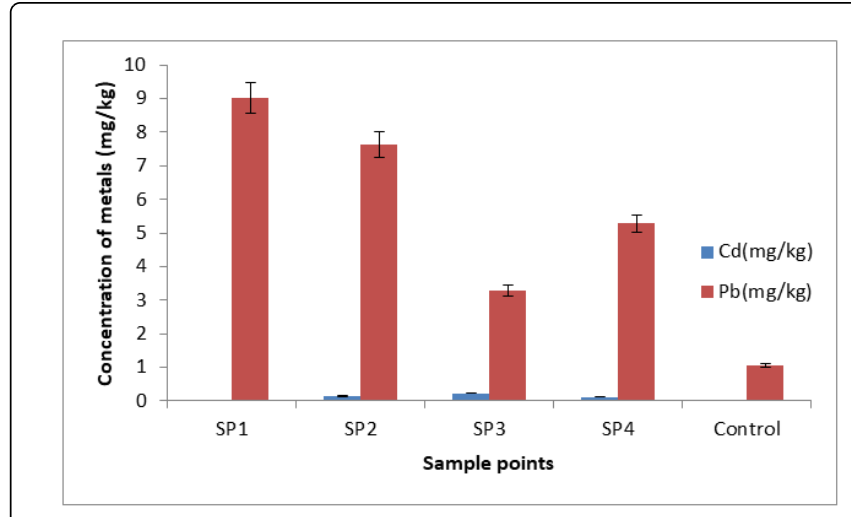

Figure 2: Showing chart of concentration of metals in barbecue.

Lead concentration in barbecue was in the range 3.30-9.01 \pm 0.45 $\mathrm{mg} / \mathrm{kg}$, this concentration is found to be higher than that observed by Desideri in cattle meat which was $0.6 \pm 03 \mathrm{ppm}$ (Figure 2) [35]. Lead concentration in barbecue may be high as a result of vehicular and industrial emission contribution, as it has been known that Lead fuel combustion is a veritable source of Lead contamination. The Lead concentration in barbecue was the second highest when compared to that obtained from roasted corn and roasted plantain. Lead obtained from SP1 and SP2, Tollgate and Agege respectively seems to have higher concentration compared to SP3 and SP4, Joju and Oju-ore respectively. This may be expected as Tollgate and Agege had car parks which tend to make the Lead concentration higher. The concentration of Lead in the control samples were lower than all the samples analysed in this study, which could be indication that vehicular and industrial emission increase the particulate emission in the environment as well as food. The concentration of Lead in control samples of barbecue was higher than FAO/WHO limits in foods which may be an indication of exposures of the cows while breeding through contaminated grass. Lead in barbecue were higher than the FAO/WHO recommended limit of Lead in foods, which is an indication that barbecue on highway traffic and industrial emission may be a source of exposure.

Cadmium in roasted corn (Zea mays) was in the range 0.32-1.10 \pm $0.05 \mathrm{mg} / \mathrm{kg}$ (Table 3). This is lower than that observed by Jamali in corn grown on sewage sludge which had an average of $0.68 \pm 0.022$ ppm (Figure 3) [36]. Roasted corn had the highest concentration of Cadmium in all types of food analyzed. SP2 and SP3, Agege and Joju respectively seem to have higher Cadmium concentration as compared to that obtained from SP1 and SP4, Tollgate and Oju-ore respectively. This may be expected, as Agege and Joju tends to have vehicular as well as industrial contribution to the heavy metal concentration. Cadmium in roasted corn (Zea mays) was the highest in all the samples analysed. However the concentration of Cadmium in all the control samples analysed were lower than that of the samples. But $75 \%$ of food samples obtained from Agege had Cadmium concentration that is higher than the FAO/WHO recommended limit of food and additives. Mean concentration of Cadmium in the ready to eat food samples were in the order $\mathrm{SP} 2>\mathrm{SP} 3>\mathrm{SP} 4>\mathrm{SP} 1$, which may seem to suggest that the influence of particulate exposure of Cadmium due to vehicular emission are in such order in this research study. 


\begin{tabular}{|l|l|l|}
\hline Sample sites & $\mathbf{C d}(\mathbf{m g} / \mathbf{k g})$ & $\mathbf{P b}(\mathbf{m g} / \mathbf{k g})$ \\
\hline SP1 & $0.32 \pm 0.02$ & $5.75 \pm 0.30$ \\
\hline SP2 & $1.10 \pm 0.05$ & $8.14 \pm 0.41$ \\
\hline SP3 & $0.70 \pm 0.04$ & $6.86 \pm 0.34$ \\
\hline SP4 & $0.54 \pm 0.03$ & $9.10 \pm 0.46$ \\
\hline Control & ND & $2.98 \pm 0.31$ \\
\hline SP=Sample Point ND=Not Detected & & \\
\hline
\end{tabular}

at most other sample points and that food transfer of Cadmium in the area of study is not significant, but the Cadmium contamination if not checked could further increase and give rise to the increased level of exposure later, especially to the people who patronize and eat food from these sources which could be detrimental to their health as Cadmium is non-biodegradable and it could still be effective for many years later. However Lead concentration was found to be higher than the permissible level by the FAO which was $0.3 \mathrm{mg} / \mathrm{kg}$ in $92 \%$ of the total samples analyzed, which implies that food transfer of Lead in this study area is significant. This seems to suggest that road side food from the study area could be source of exposure to Lead which could make the persistent consumers of the roadside foods prone to health implications associated with persistent Lead exposure.

Table 3: Showing mean concentration of metals in roasted corn.

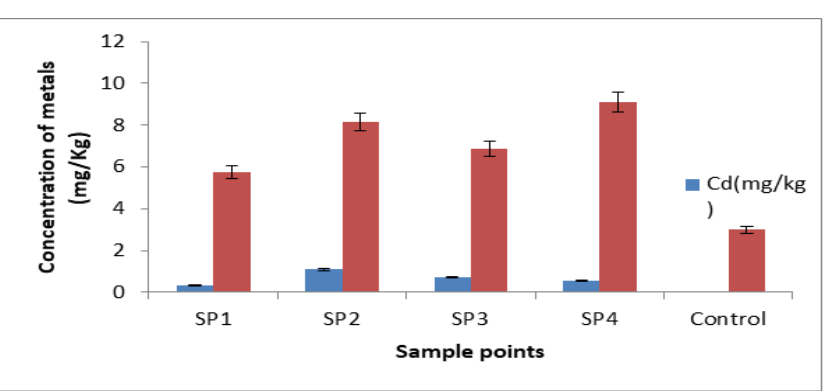

Figure 3: Showing chart of concentration of metals in roasted corn.

Lead concentration in roasted corn (Zea mays) was in the range $5.75-8.14 \pm 0.41 \mathrm{mg} / \mathrm{kg}$ (Figure 3 ). This is higher than that observed by Mok which was $0.066-0.831 \pm 0.229 \mathrm{ppm}$ [37]. Lead in roasted corn (Zea mays) was the highest concentration observed in all the sample points analyzed. Lead may be high as a result of vehicular and industrial emission contribution to the concentration of Lead. While Lead concentration at SP2 and SP4, Agege and Oju-ore respectively seems to be only a slightly higher difference in Lead concentration compared to that obtained from SP1and SP3, Tollgate and Joju respectively. Lead in the control samples were lower than that in all of the samples analysed in this study. Lead concentration in all roasted corn (Zea mays) samples were higher than the FAO/WHO recommended limit in food and additives, this seems to suggest that roasted corn on sources close to highway and industrial emission is a source of Lead exposure. The mean concentration of Lead in the ready to eat food samples decreased from one site to another in the order $\mathrm{SP} 2>\mathrm{SP} 1>\mathrm{SP} 4>\mathrm{SP} 3$, which may seems to suggest that Lead exposure as a result of particulate emission through industrial and vehicular sources followed the order in the food samples studied.

\section{Conclusion}

The results obtained from this study revealed that high industrial and vehicular emission increase the particulate emission in the atmosphere which in turn impact on the environment and food in the vicinity. The results showed that the order of the concentration of Lead in the food samples was corn $>$ barbecue $>$ plantain and the order of the Cadmium concentration in the food samples was in the order corn $>$ plantain $>$ barbecue. Cadmium was high only in roasted corn at $25 \%$ of all the samples analyzed of the research as compared to the permissible concentration allowed by the FAO which is $0.5 \mathrm{mg} / \mathrm{kg}$, this seems to suggest that the concentration is still at the contaminant level

\section{Conflict of Interest}

The authors declare that there is no conflict of interest.

\section{References}

1. Soylak M, Aydin A (2011) Determination of some heavy metals in food and environmental samples by flame atomic absorption spectrometry after co-precipitation. Food and Chemical Toxicology 49: 1242-1248.

2. De Silva S, Ball AS, Huynh T, Reichman SM (2016) Metal accumulation in roadside soil in Melbourne, Australia: Effect of road age, traffic density and vehicular speed. Environmental Pollution 208: 102-109.

3. Requia WJ, Adams MD, Arain A, Koutrakis P, Lee W, et al. (2017) Spatiotemporal analysis of particulate matter intake fractions from vehicular emissions: Hourly variation by micro-environments in the Greater Toronto and Hamilton area, Canada. Science of the Total Environment 599-600: 1813-1822.

4. Adewuyi GO, Dawodu FA, Jibiri NN (2010) Studies of the Concentration Level of Heavy Metals in Vegetable (Amaranthus caudatus) Grown in Dumpsites within Lagos Metropolis, Nigeria. The Pacific Journal of Science and Technology 11: 616-621.

5. Pokorny B, Ribaric-Lasnik C (2002) Seasonal variability of mercury and heavy metals in roe deer (Capreolus capreolus) kidney. Environmental Pollution 117: 35-46.

6. Ikem A, Egiebor NO (2005) Assessment of trace element in canned fishes (Mackerel, Tuna, Salmon Sardines and Herring) marketed in Georgia and Alabama (United States of America). Journal of Food Composition and Analysis 18: 771-787.

7. Onianwa PC, Adeyemo AO, Idowu OE, Ogabiela EE (2001) Copper and zinc contents of Nigerian foods and estimates of the adult dietary intakes. Food Chemistry 72: 89-95.

8. Orisakwe OE, Nduka JK, Amadi CN, Dike DO, Bede O (2012) Heavy metal health risk assessment for pollution via consumption of food crops and fruits in Owerri, south eastern Nigeria. Chemistry Central Journal 6: $1-7$.

9. Arulkumar A, Paramasivam S, Rajaram R (2017) Toxic heavy metals in commercially important food fishes collected from Palk Bay Southeastern India. Marine Pollution Bulletin 119: 454-459.

10. Kilic Z, Acra O, Ulasan M, Ilim M (2002) Determination of lead, copper, zinc, magnesium, calcium and iron in fresh egg by atomic absorption spectrometry. Food Chemistry 76: 107-116.

11. Rahimi E (2013) Lead and Cadmium concentration in goat, cow, sheep and buffalo milk from different regions of Iran. Food Chemistry 136: 389-391.

12. Akinseye VO (2013) Electronic waste component in developing countries; harmless substances or potential carcinogen. Annual Review and Research in Biology 3: 131-147.

13. Ofori H, Owusu M, Anyebuno GO (2013) Heavy Metals Analysis of Fruit Juice and Soft Drinks Bought from Retail Market in Accra, Ghana. Journal of Scientific Research and Report 2: 423-428. 
14. Almeida JA, Novelli ELB, Dal Pai Silva M, Alves Jr R (2001) Environmental Cadmium exposure and metabolic response of the Nile tilapia Oreochromis niloticus. Environmental Pollution 114: 169-175.

15. Aborisasade OB, Charles-Davies MA, Okunola MA (2013) Environmental Influences in Normal Weight Women with History of Recurrent Pregnancy Loss. International Journal of Tropical Diseases 3: 257-266.

16. Shah AQ, Kazi TG, Arain MB, Jamali MK, Afridi HI, et al. (2009) Comparison of electrothermal and hydride generation atomic absorption spectrometry for the determination of total arsenic in broiler chicken. Food Chemistry 113: 1351-1355.

17. Liao CM, Chen BC, Singh S, Lin MC, Liu CW, et al. (2003) Acute toxicity and bioaccumulation of arsenic in Tilapia (Oreochromis mossambicus) from a black foot disease are in Taiwan. Environ Toxicol 18: 252-259.

18. Babayemi JO, Ololade ZS, Onipede OJ, Dauda KT (2012) Evaluation of Livestock Dung for Potash Alkali and Metal Content. International Journal of Applied Research and Technology 1: 107-112.

19. Burt R, Wilson MA, Keck TJ, Dougherty BD, Strom DE, et al. (2003) Trace element speciation in selected smelter-contaminated soil in Anaconda and Deer lodge valley, Montana, USA. Advances in Environmental Research 8: 51-67.

20. Frost HL, Ketchum Jr LH (2000) Trace metal concentration in durum wheat from application of sewage sludge and commercial fertilizer. Advances in Environmental Research 4: 347-355.

21. Ganjavi M, Ezzalpanah H, Givianrad MH, Shams A (2010) Effect of canned tuna fish processing steps on lead and cadmium content of Iranian tuna fish. Food Chemistry 118: 525-528.

22. Cai Q, Long M, Zhu M, Zhang L, Liu J (2009) Food chain transfer of cadmium and lead to cattle in a lead-zinc smelter in Guizhou, China. Environmental Pollution 157: 3078-3082.

23. Moiseenko TI, Kudryavtseva LP (2001) Trace metal accumulation and fish pathologies in areas affected by mining and metallurgical enterprises in Kola region Russia. Environmental Pollution 114: 285-297.

24. Moreira CM, Duarte FA, Lebherz J, Pozebon D, Flores EMM, et al. (2011) Arsenic speciation in white wine by LC-ICP-MS. Food Chemistry 126: 1406-1411.

25. Ahrens L, Marusczak N, Rubarth J, Dommergue A, Nedjai R, et al. (2010) Distribution of perfluoroalkyl compounds and mercury in fish liver from mountain lakes in France originating from atmospheric deposition. Environ Chem 7: 422-428.
26. Karavoltsos S, Sakellari A, Dassenakis M, Scoullos M (2008) Cadmium and lead in organically produced foodstuff from Greek market. Food Chemistry 106: 843-851.

27. Austin J, Brimblecombe P, Sturges W (2002) Air Pollution Science for the 21st Century, Volume 1. 1st Edition, Elsevier Science.

28. Ngah CWZCW, Yahya MA (2012) Optimisation and digestion method for determination of arsenic in shrimp paste sample using atomic absorption spectrometry. Food Chemistry 134: 2406-2410.

29. Franca FCSS, Albuuerque AMA, Almeida AC, Silveira PB, Filho CA, et al. (2017) Heavy metals deposited in the culture of lettuce (Lactuca sativa L) by the influence of vehicular traffic in Pernambuco, Brazil. Food Chemistry 215: 171-176.

30. Greffeuille V, Kayode APP, Icad-Verniere C, Gnimadi M, Rochette I, et al. (2011) Changes in iron, zinc and chelating agent during traditional African processing of maize: Effect of iron contamination on bioaccessibility. Food Chemistry 126: 1800-1807.

31. Emaga TH, Andrianaivo RH, Wathelet B, Tchango JT, Paquot M (2007) Effect of the stage of maturation and varieties on the chemical composition of banana and plantain peels. Food Chemistry 103: 590-600.

32. Korn MGA, Morte ESB, Santos DCMB, Castro JT, Barbosa JTP, et al. (2008) Sample Preparation For The Determination Of Metals In Food Samples Using Spectroanalytical Methods. Applied Spectroscopy Reviews 43: 67-92.

33. FAO/WHO (1989) Recommended Dietary Allowance. 10th Edition, National Research Council, National Academy Press, Washington, DC, USA.

34. Amos-Tautua BMW, Inengite AK, Abasi CY, Amirize GC (2013) Evaluation of polycyclic aromatic hydrocarbons and some heavy metals in roasted food snacks in Amassoma, Niger Delta, Nigeria. Africa Journal of Environmental Science and Technology 7: 961-966.

35. Desideri D, Meli MA, Cantaluppi C, Ceccotto F, Roselli C, et al. (2012) Essential and toxic elements in meat of wild and bred animals. Toxicological and Environmental Chemistry 94: 1995-2005.

36. Jamali MK, Kazi TG, Arain MB, Afridi HI, Jabani N, et al. (2006) The correlation of total and extractable heavy metals from soil and domestic sewage sludge and their transfer to maize (Zea mays L.) plants. Toxicological and Environmental Chemistry 88: 619-632.

37. Mok WJ, Senoo S, Itoh T, Tsukamasa Y, Kawasaki K, et al. (2012) Assessment of concentrations of toxic elements in aquaculture food products in Malaysia. Food Chemistry 133: 1326-1332. 